\title{
Pembangunan Sistem Informasi Geografis Penyebaran Lokasi Usaha Florist Berbasis Web di Kota Padang
}

\author{
Rafel Dinur ${ }^{a}{ }^{*}$, Haris Suryamen ${ }^{a}$, Fajril Akbar $^{a}$ \\ a Jurusan Sistem Informasi Fakultas Teknologi Informasi Universitas Andalas
}

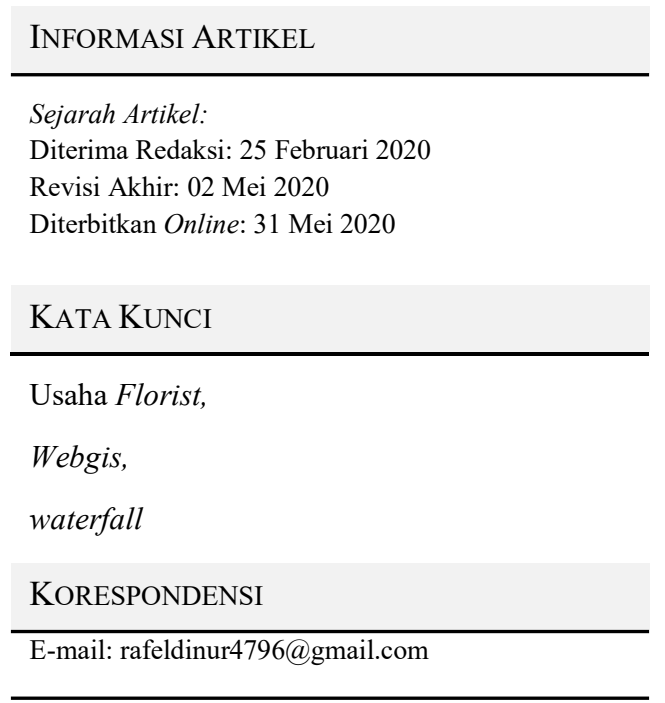

\section{PENDAHULUAN}

Usaha florist adalah salah satu industri kecil menengah yang saat ini banyak sekali ditemukan. Florist merupakan istilah yang biasa digunakan untuk menggambarkan perdagangan bunga profesional. Meliputi perawatan bunga dan penanganan, desain bunga atau merangkai bunga, pemesanan, menampilkan, merchandising serta pengiriman bunga. Produk yang dihasilkan dalam usaha florist bermacam-macam. Produk dapat berupa bunga papan, rangkaian bunga, buket bunga, bunga setangkai baik bunga asli maupun bunga artifisial. Masing-masing produk memiliki fungsi yang berbeda. Selain menjual produk, usaha florist juga menjual jasa dalam bentuk pelayanan berupa pengantaran bunga, perawatan bunga, dan banyak lagi [1]. Saat ini banyak jenis karangan bunga yang bisa didapatkan di toko florist. Produk yang ada dalam usaha florist tidak hanya berupa produk bunga. Usaha florist juga menyediakan jasa dalam bentuk pelayanan [2].
Menurut data Dinas Koperasi dan UKM (Diskopukm) Kota Padang pada tahun 2019, terdapat 57 usaha florist yang terdaftar dari seluruh bagian kecamatan yang ada di Kota Padang. Industri kecil seperti usaha florist yang ada di Kota Padang belum maksimal dalam pemasaran dan pelayanan produknya. Masih kurangnya informasi mengenai lokasi dan layanan pemesanan disetiap usaha florist yang ada, menyebabkan konsumen kesulitan dalam proses pemesanan karangan bunga. Usaha florist dalam mempromosikannya masih menggunakan brosur atau dengan spanduk dan penyimpanan data masih berupa arsip sehingga sering terjadinya kesalahan data dan kehilangan data. Ada beberapa situs penjualan bunga (florist) secara online, tetapi website toko bunga tersebut hanya memberikan informasi dan menjelaskan spesifikasi penjualan bunga melalui Short Message Service (SMS) dan telepon saja [3]. Bagi petugas Diskopukm mengalami kesulitan dalam pengawasan usaha florist terkait prosedur, surat, dan izin dalam melakukan usaha yang berkaitan dengan jasa pemesanan karangan bunga karena adanya 
usaha florist yang tidak terdeteksi keberadaannya maupun pendirian usaha tanpa izin [4].

Industri kecil seperti usaha florist yang ada di Kota Padang belum maksimal dalam pemasaran dan pelayanan produknya. Masih kurangnya informasi mengenai lokasi dan layanan pemesanan disetiap usaha florist yang ada, menyebabkan konsumen kesulitan dalam proses pemesanan karangan bunga. Pemesanan karangan bunga biasanya dilakukan dengan proses manual via media seluler atau datang langsung ke toko florist tersebut sehingga kurang efisien dari segi waktu dan proses. Pemesanan karangan bunga yang dilakukan masyarakat/calon pemesan saat ini masih dengan cara mencari terlebih dahulu informasi terkait usaha florist dalam hal harga dan ketersediaan produk karangan bunga yang diinginkan, yaitu dengan mengunjungi langsung ke toko usaha florist yang dituju, sehingga hal tersebut memakan waktu yang cukup lama dan menghabiskan tenaga yang lebih karena harus menanyakan langsung ke toko florist.

Teknologi informasi saat ini berkembang dengan sangat pesat, sehingga kebutuhan untuk mendapatkan suatu informasi yang cepat telah menjadi kebutuhan pokok masyarakat. Salah satunya adalah kebutuhan akan informasi geografis suatu daerah atau dikenal dengan Sistem Informasi Geografis (SIG). Untuk merancang sebuah sistem yang mampu menangkap, menyimpan, memanipulasi, menganalisa, mengatur, dan menapilkan data geografis dibutuhkan suatu SIG [5]. Pengertian SIG menurut [6] pengelolaan informasi untuk data spasial bergeoreferensi yang disimpan dalam suatu basis data yang dapat diolah datanya berupa fakta, detail, kondisi yang berhubungan dengan dunia nyata. Teknologi SIG merupakan suatu teknologi geografis yang memiliki kemampuan dalam mengumpulkan, mengelola, memanipulasi dan memvisualisasikan data spasial (keruangan) yang berhubungan dengan posisi dipermukaan bumi pada sebuah peta yang sesuai dengan posisi permukaan bumi yang sebenarnya sesuai dengan titik koordinatnya [7].

Dari permasalahan diatas dapat disimpulkan bahwa dibutuhkan sebuah SIG florist berbasis web, atau lebih dikenal dengan Web GIS. Web GIS merupakan suatu Sistem Informasi Geografis (SIG) yang dapat terhubung ke dalam jaringan internet yang digunakan untuk mengumpulkan, mencatat, mendokumentasi dan menyajikan data informasi serta mengidentifikasikan lokasi objek mengguanakan web tanpa adanya kebutuhan penggunaan software SIG [8]. Dengan adanya SIG berbasis web, Diskopukm dan masyarakat dapat dengan mudah mengakses dan mengelola informasi kapanpun, karena mampu memberikan layanan akses 24 jam dalam sehari dengan menggunakan layanan internet [9].

Dengan SIG penyebaran lokasi usaha florist dengan fitur pendaftaran pemesanan berbasis web di Kota Padang dapat mempermudah pemerintah Kota Padang dalam memberikan informasi terbaru mengenai usaha florist sehingga dapat bertukar informasi melalui koneksi internet dengan masyarakat dan mempermudah masyarakat atau konsumen untuk menemukan, memesan dan mendapatkan informasi mengenai lokasi usaha florist di Kota Padang.

Penelitian yang dilakukan oleh Hendy Setiady dan Yulistia ini tujuannya adalah untuk membangun aplikasi yang mewadahi para usaha rangkaian bunga untuk mempromosikan produk di website dengan lebih efektif dan efisien serta dapat memberikan informasi lengkap mengenai rangkaian bunga yang diinginkan bagi calon pembeli. Dengan adanya sistem informasi pemesanan dan penjualan rangkaian bunga berbasis website ini memberikan gambaran kepada calon pembeli untuk merencanakan rangkaian bunga yang ingin dipesan dengan informasi-informasi yang tersedia di website pemesanan dan penjualan rangkaian bunga ini. Dengan adanya aplikasi ini, diharapkan pembeli dapat memanfaatkan teknologi untuk mencari referensi tanpa harus keluar rumah untuk mencari tempat penjual rangkaian bunga [10]. Penelitian selanjutnya yang dilakukan oleh Agustian, dkk ini bertujuan untuk membangun aplikasi yang mampu memfasilitasi para pemilik lapangan futsal untuk mempromosikan lapangan futsal yang dikelolanya kepada masyarakat (pelanggan) dan juga mempermudah calon pemesan lapangan futsal untuk menemukan lokasi lapangan yang tersedia [11]. Penelitian selanjutnya yang dilakukan oleh Taroreh berutujuan untuk mampu memfasilitasi pengguna dengan menyediakan fitur pencarian layanan produk/jasa penjualan bunga. Aplikasi penjualan bunga dapat menjadi media promosi jasa layanan bagi penjualan bunga. Hasil keluaran dari sistem ini adalah model barang yang yang akan dijual kepada pelanggan [12]. Penelitian selanjutnya yang dilakukan oleh Nuryamin dan Dewi ini berutujuan untuk sebagai alat bantu dalam pengolahan data dapat mempermudah pengolahan data transaksi dengan cara yang lebih mudah dan efisien dan penyimpanan data dapat menghemat tempat, memudahkan dalam pencarian data pada saat perbaikan dan rekap data serta masyarakat lebih mudah mengakses informasi tentang hasil karya Toko Florist baik itu yang terbaru sekalipun [13]. Penelitian selanjutnya yang dilakukan oleh Antonio, dkk ini berutujuan untuk membuat website untuk memudahkan Toko Amai dalam mempromosikan produk yang dimilikinya secara lebih luas dan membuat website untuk melakukan pemesanan dan penjualan bunga secara online. Dengan adanya sistem informasi pada Toko Bunga Amai berbasis website ini memberikan gambaran kepada calon pembeli untuk merencanakan bunga yang ingin dipesan dengan informasiinformasi yang tersedia di website pemesanan dan penjualan bunga ini [14].

Bagaimana membangun SIG penyebaran lokasi usaha florist serta fitur pendaftaran pemesanan berbasis web di Kota Padang. Tujuan ini diuraikan sebagai berikut :

1. Menganalisis kebutuhan fungsional yang diperlukan pada sistem yang akan dibangun.

2. Merancang dan membangun SIG penyebaran lokasi usaha florist serta fitur pendaftaran pemesanan berbasis web di Kota Padang

3. Menguji SIG posisi toko usaha florist dan proses pendaftaran pemesanan. 


\section{METODE}

Metode penelitian yang diterapkan dalam penelitian ini dimulai dari studi pendahuluan dan studi literatur. Studi pendahuluan dilakukan dengan melakukan pengamatan, pencarian informasi mengenai usaha florist analisis proses pendaftaran pemesanan di usaha florist. Untuk studi literatur dilakukan dengan memahami penelitianpenelitian sebelumnya yang terkait dengan topik penelitian. Selanjutnya dilakukan pengumpulan data-data yang terkait dengan penelitian yang dilakukan. Tahapan ini menghasilkan alur sistem dalam pendaftaran pemesanan yang sedang berjalan di usaha florist.

Tahap selanjutnya adalah analisis sistem dan pengumpulan kebutuhan sistem, dilakukan dengan cara menganalisis apa saja yang dibutuhkan user dan pemodelan sistem baru yang diusulkan. Hasil dari tahap ini yaitu pemodelan proses bisnis, use case diagram, dan use case scenario. Tahap selanjutnya adalah melakukan perancangan sistem. Perancangan sistem terdiri dari beberapa tahapan yaitu perancangan database (ERD), desain user interface, dan rancangan arsitektur aplikasi.

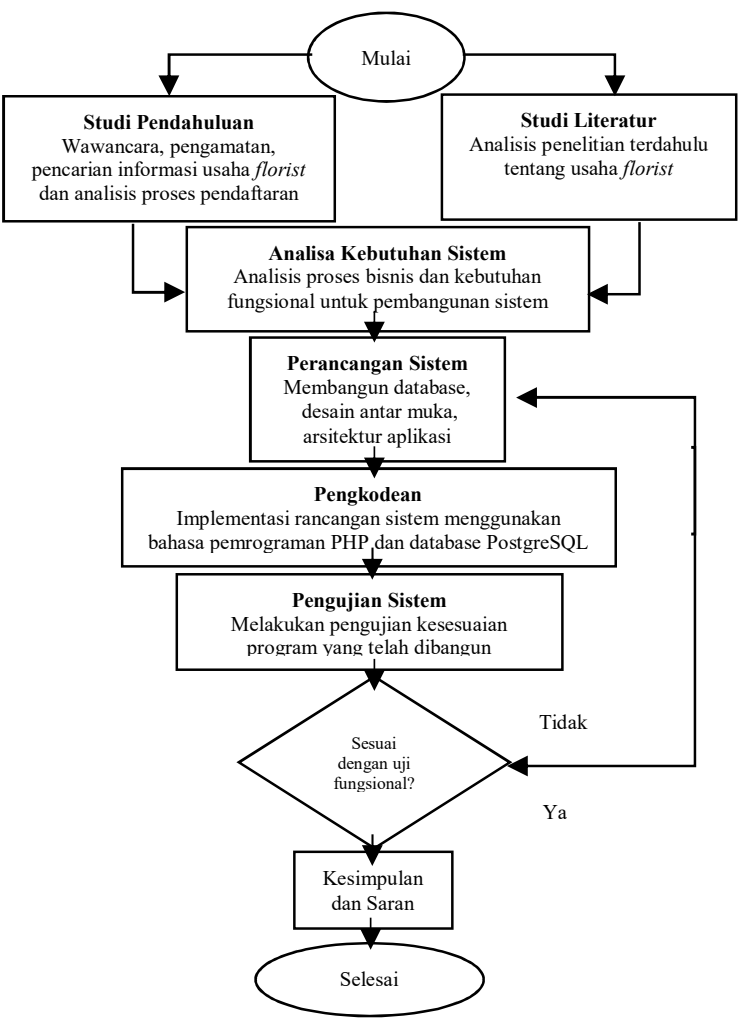

Gambar 1. Flowchart Penelitian

Setelah dilakukan perancangan sistem, tahapan selanjutnya yaitu implementasi ke dalam pengkodean. Implementasi sistem menggunakan bahasa pemrograman PHP, dan database PostgreSQL. Hasil dari tahapan ini yaitu aplikasi sisten informasi geografis penyebaran lokasi usaha florist serta fitur pendaftaran pemesanan berbasis di Kota Padang yang siap digunakan sesuai dengan rancangan sistem yang telah diusulkan. Pengujian sistem adalah tahap selanjutnya setelah implementasi ke dalam pengkodean selesai. Pengujian sistem menggunakan metode Black
Box Testing [15] yang dilakukan oleh pengguna yang terlibat dalam sistem yaitu calon pemesan, admin pengelola usaha, dan super admin. Pengujian dilakukan untuk mengetahui apakah sistem yang dikembangkan sesuai dengan fungsional dan kebutuhan user. Jika terdapat ketidaksesuaian maka tahapan kembali ke perancangan sistem, tetapi jika sesuai maka akan dilanjutkan pada tahap kesimpulan dan saran. Tahapan-tahapan penelitian ini digambarkan pada flowchart penelitian pada Gambar 1.

Tahapan metode pembangunan sistem pada pembangunan aplikasi sistem informasi geografis penyebaran lokasi usaha florist serta fitur pendaftaran pemesanan berbasis web di Kota Padang sampai pada tahap pengujian. Tahapan metodenya adalah sebagai berikut :

1. Fase Analisis

Pada fase ini dilakukan pengumpulan data, masalah yang harus dipecahkan, dan studi literatur untuk mengetahui kebutuhan yang diperlukan dalam pembangunan aplikasi. Dari fase inilah dapat diketahui data yang dibutuhkan dalam pembangunan aplikasi berupa data spasial dan atribut dalam sistem. Pada pengembangan SIG penyebaran lokasi usaha florist serta fitur pendaftaran pemesanan berbasis web di Kota Padang, analisis akan menghasilkan usecase diagram dan data flow diagram. Usecase diagram dan data flow diagram dihasilkan dengan mendefinisikan fungsional sistem.

2. Fase Perancangan atau Desain

Pada fase ini dilakukan perancangan sistem yang dibangun. Tahap ini dilakukan sebelum melakukan pengkodean. Pada tahap ini dilakukan perancangan arsitektur sistem, perancangan basis data, perancangan antarmuka sistem dan proses.

3. Fase Implementasi (Pengkodean)

Pada fase ini dilakukan proses pembuatan basis data, user interface, dan pengkodean berdasarkan perancangan yang telah dilakukan dan mengimplementasikannya kedalam kode dengan menggunakan bahasa pemrograman tertentu. Aplikasi dibangun menggunakan javascript, dan bahasa pemrograman PHP untuk mengakses web server.

4. Fase Testing atau Pengujian

Pada fase ini dilakukan pengujian terhadap aplikasi yang dibangun. Pengujian dilakukan dengan metode blackbox testing dengan cara memasukkan data dan melihat luaran dari aplikasi. Jika luaran dari data yang dimasukkan sesuai dengan hasil yang diharapkan, maka aplikasi tersebut lulus dari pengujian.

\section{HASIL}

$\mathrm{Bab}$ ini menjelaskan mengenai analisis kebutuhan dan perancangan sistem dari aplikasi SIG penyebaran lokasi usaha florist serta fitur pendaftaran pemesanan berbasis web di Kota Padang. Analisis terdiri dari analisis sistem dan analisis kebutuhan. Analisis sistem terdiri dari proses bisnis yang berjalan dan proses bisnis yang diusulkan. Analisis kebutuhan terdiri dari kebutuhan fungsional, kebutuhan non fungsional, dan kebutuhan data spasial. Perancangan sistem terdiri dari kebutuhan fungsional sistem, perancangan basis data, perancangan user interface dan perancangan proses. 


\subsection{Analisis Sistem}

Penjelasan mengenai analisis sistem pada aplikasi ini berisikan tentang BPMN (Business Process Modelling Notation) dari proses yang sedang berjalan dan yang diusulkan, kebutuhan fungsional, usecase diagram, context diagram, dan data flow diagram.

\subsubsection{BPMN Proses yang Sedang Berjalan}

BPMN merupakan metodologi baru yang dikembangkan oleh Process Modeling Initiative sebagai suatu standar baru pada pemodelan proses bisnis. BPMN memiliki tujuan utama yaitu untuk menyediakan suatu notasi standar yang mudah dipahami oleh semua pengguna, yang meliputi bisnis analis saat memodelkan proses bisnis, pengembangan teknik yang membangun sistem untuk melaksanakan bisnis sehingga dapat membantu dalam pengambilan keputusan [16].

Proses pemesanan karangan bunga ini didapatkan berdasarkan hasil dari wawancara pada beberapa usaha florist yang ada di Kota Padang yaitu, sebagai berikut :

1. Calon pemesan mengunjungi usaha florist dan menanyakan harga karangan bunga.

2. Pihak pengelola usaha florist akan memberikan daftar barang kepada calon pemesan. Daftar barang dapat berupa daftar harga beserta ketersediaan barang.

3. Jika harga dan barang pesanan yang dipilih sesuai dengan calon pemesan inginkan, calon pemesan akan memilih memesan berdasarkan daftar barang yang telah dipilih oleh pemesan. Setelah itu calon pemesan akan menanyakan ketersediaan usaha florist dalam menyediakan daftar barang yang ingin dipesan calon pemesan sesuai yang diinginkan. Jika harga dan pilihan barang tidak sesuai maka proses selesai.

4. Pihak pengelola usaha florist akan mencatat pesanan calon pemesan.

5. Pemesan menerima bukti pendaftaran pemesanan.

Menurut analisis dari alur pendaftaran pemesanan yang telah diuraikan, maka BPMN alur pendaftaran pemesanan di usaha florist yang sedang berlangsung dapat dilihat pada Gambar 2 .

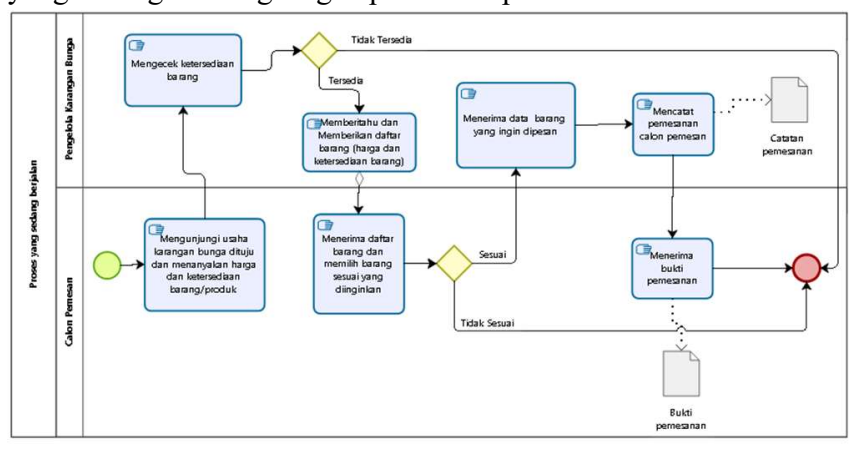

Gambar 1. BPMN Proses Yang Sedang Berjalan

\subsubsection{BPMN Proses yang Diusulkan}

Berdasarkan analisis yang telah dilakukan pada pemesanan karangan bunga ini, terdapat beberapa proses yang diusulkan yaitu, sebagai berikut :
1. Calon pemesan mencari dan menentukan usaha florist yang dituju dengan melihat informasi mengenai harga dan ketersediaan karangan bunga sebelum melakukan pendaftaran pemesanan.

2. Setelah menentukan usaha florist yang dituju, calon pemesan akan mengisi form pendaftaran pemesanan pada usaha florist yang dipilih. Data yang diinputkan yaitu berupa data lokasi pengiriman, tanggal pengiriman, text ucapan karangan bunga, dan barang pesanan yang diinginkan.

3. Setelah itu pihak pengelola usaha florist akan melakukan konfirmasi status pendaftaran pemesanan, jika pihak usaha pengelola telah mengkonfirmasi maka akan keluar status pemesanan yaitu dikonfirmasi.

4. Jika dikonfirmasi maka calon pemesan bisa mencetak bukti pendaftaran pemesanan sebagai bukti pendaftaran pemesanan.

Sesuai dengan paparan analisis dari alur pendaftaran pemesanan yang diusulkan, dilakukan mempersingkat alur proses yang mana sebelumnya calon pemesan banyak melakukan kegiatan sebelum mendaftar pemesanan seperti mengunjungi usaha florist untuk memeriksa kesesuaian harga dan barang yang tersedia. Pada alur pendaftaran pemesanan yang diusulkan, calon pemesan bisa melakukan kegiatan tersebut menggunakan sistem yang akan dibangun. BPMN alur pendaftaran yang diusulkan dapat dilihat pada Gambar 3.

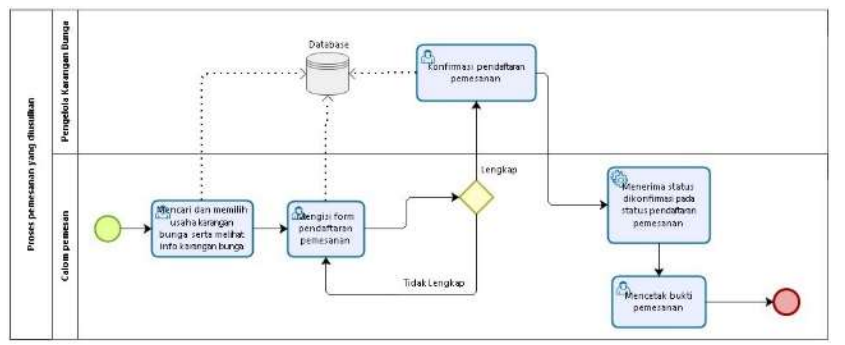

Gambar 2. BPMN Proses Yang Diusulkan

\subsubsection{Kebutuhan Fungsional Sistem}

Kebutuhan fungsional untuk SIG penyebaran lokasi usaha florist serta pendaftaran pemesanan berbasis web di Kota Padang adalah sebagai berikut:

1. Calon pemesan, admin pengelola usaha, dan super admin dapat login dan logout.

2. Calon pemesan, admin pengelola usaha, dan super admin dapat melihat data diri (profil akun)

3. Calon pemesan, admin pengelola usaha, dan super admin dapat mengubah password

4. Calon pemesan dapat melihat posisinya saat ini ketika menggunakan sistem.

5. Calon pemesan dapat melihat posisi manual ketika menggunakan sistem.

6. Calon pemesan dapat melihat semua posisi toko usaha florist ketika menggunakan sistem.

7. Calon pemesan dapat melakukan pencarian lokasi usaha florist berdasarkan nama toko usaha. 
8. Calon pemesan dapat melakukan pencarian lokasi usaha florist berdasarkan kecamatan.

9. Calon pemesan dapat melakukan pencarian lokasi usaha florist berdasarkan radius.

10. Calon pemesan dapat melakukan pencarian posisi toko usaha florist terdekat dari posisi toko yang paling dekat dengan toko yang dipilih beserta jaraknya.

11. Calon pemesan dapat melakukan pencarian lokasi usaha florist berdasarkan jenis barang tersedia yang dijual.

12. Calon pemesan dapat melihat rute dari posisi calon pemesan berada menuju lokasi usaha florist yang dipilih.

13. Calon pemesan dapat melihat detail informasi lokasi usaha florist yang dipilih seperti nama usaha, nama pengelola, alamat, nomor telepon, kode pos, dan foto.

14. Calon pemesan dapat melakukan registrasi akun.

15. Calon pemesan dapat melakukan pendaftaran pemesanan

16. Calon pemesan dapat melihat list riwayat pendaftaran pemesanan.

17. Calon pemesan dapat melihat detail pendaftaran pemesanan

18. Calon pemesan dapat melihat galeri usaha florist

19. Calon pemesan dapat melakukan pembatalan pemesanan.

20. Calon pemesan dapat melihat notifikasi konfirmasi pendaftaran pemesanan

21. Calon pemesan dapat mencetak bukti pendaftaran pemesanan setelah dikonfirmasi.
22. Admin pengelola usaha florist melihat dan mengubah data informasi usaha florist

23. Admin pengelola usaha florist dapat melihat, menambah, mengubah, dan menghapus data barang tersedia.

24. Admin pengelola usaha florist dapat mengkonfirmasi pemesanan dari calon pemesan.

25. Admin pengelola usaha florist dapat melihat list pendaftaran pemesanan

26. Admin pengelola usaha florist dapat melihat notifikasi pendaftaran pemesanan baru.

27. Super admin dapat membuat/mencetak laporan list usaha florist berdasarkan kecamatan.

28. Super admin dapat melihat, menambah, mengubah, dan menghapus data usaha florist.

29. Super admin dapat melihat, menambah, mengubah, dan menghapus data akun.

30. Super admin dapat melihat, menambah, mengubah, dan menghapus data barang tersedia usaha florist.

31. Super admin dapat melihat, menambah, mengubah, dan menghapus data jenis barang usaha florist.

\subsubsection{Usecase Diagram}

Usecase dari aplikasi yang dibangun terdiri dari tiga aktor, yaitu calon pemesan, admin pengelola usaha, dan super admin. Use case dapat dilihat pada Gambar 4.

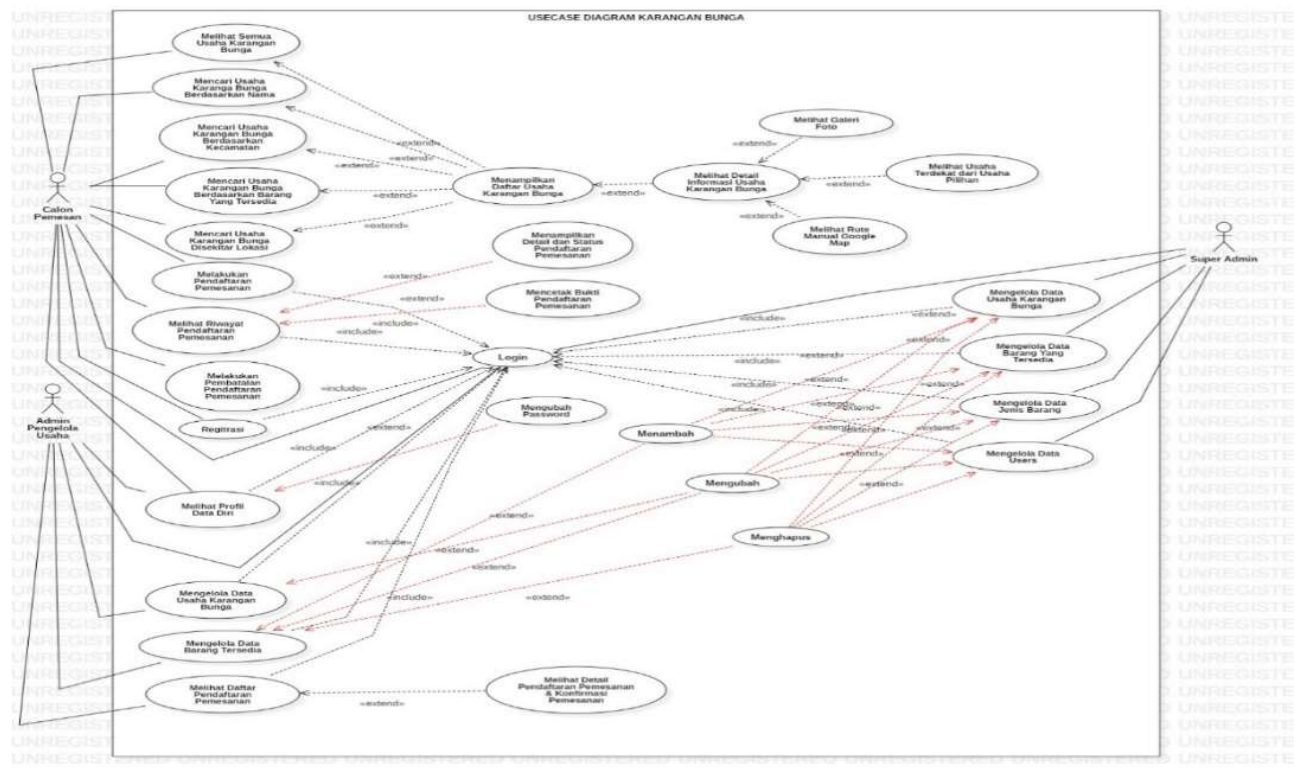

Gambar 4. Usecase Diagram

\subsubsection{Data Flow Diagram Level 1}

DFD merupakan diagram yang digunakan pada metodologi pengembangan sistem yang terstruktur. Diagram ini menggambarkan aliran data dalam suatu entitas ke sistem atau sistem ke entitas. DFD Level 1 merupakan data dari DFD Level 0 yang telah didekomposisi yaitu pada proses besar yang digambarkan dalam context diagram Rancangan data flow diagram level 1 bisa dilihat pada Gambar 5.

\subsection{Perancangan Sistem}

\subsubsection{Rancangan Basis Data}

Perancangan basis data dalam pembangunan SIG penyebaran lokasi usaha florist serta fitur pemesanan berbasis web di Kota Padang menggunakan PostgreSQL dengan ekstensi PostGIS untuk mendukung operasi spasial. Relasi antar tabel pada basis data pembangunan SIG penyebaran lokasi usaha florist serta fitur 
pemesanan berbasis web di Kota Padang dapat dilihat pada Gambar

6.

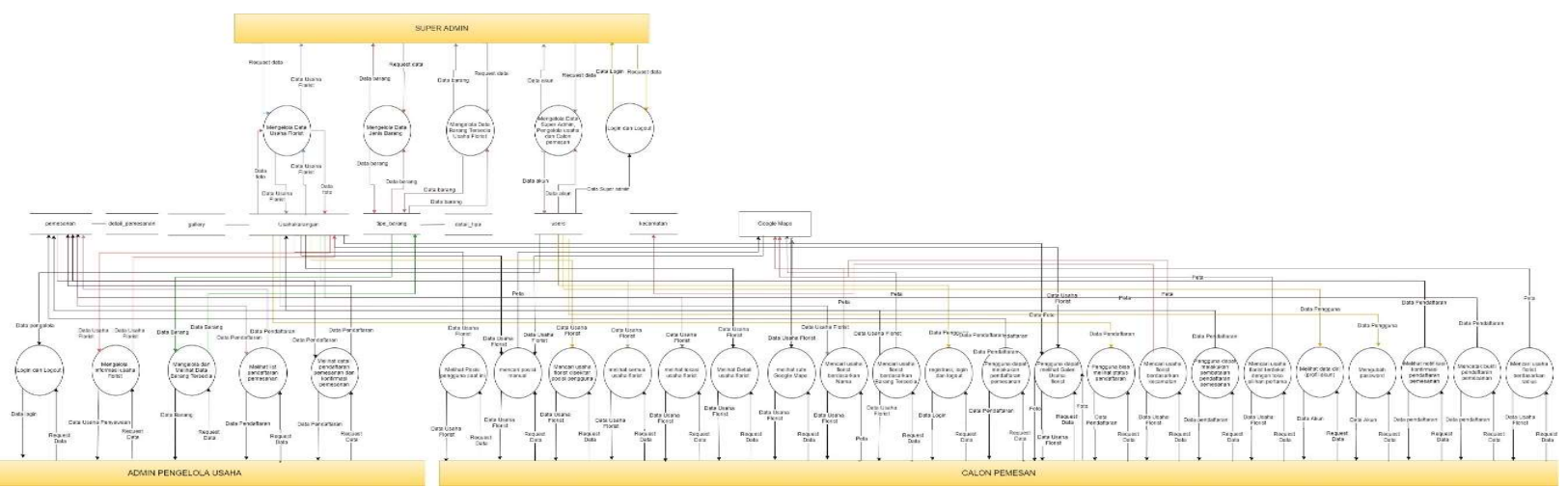

Gambar 5. DFD level 1

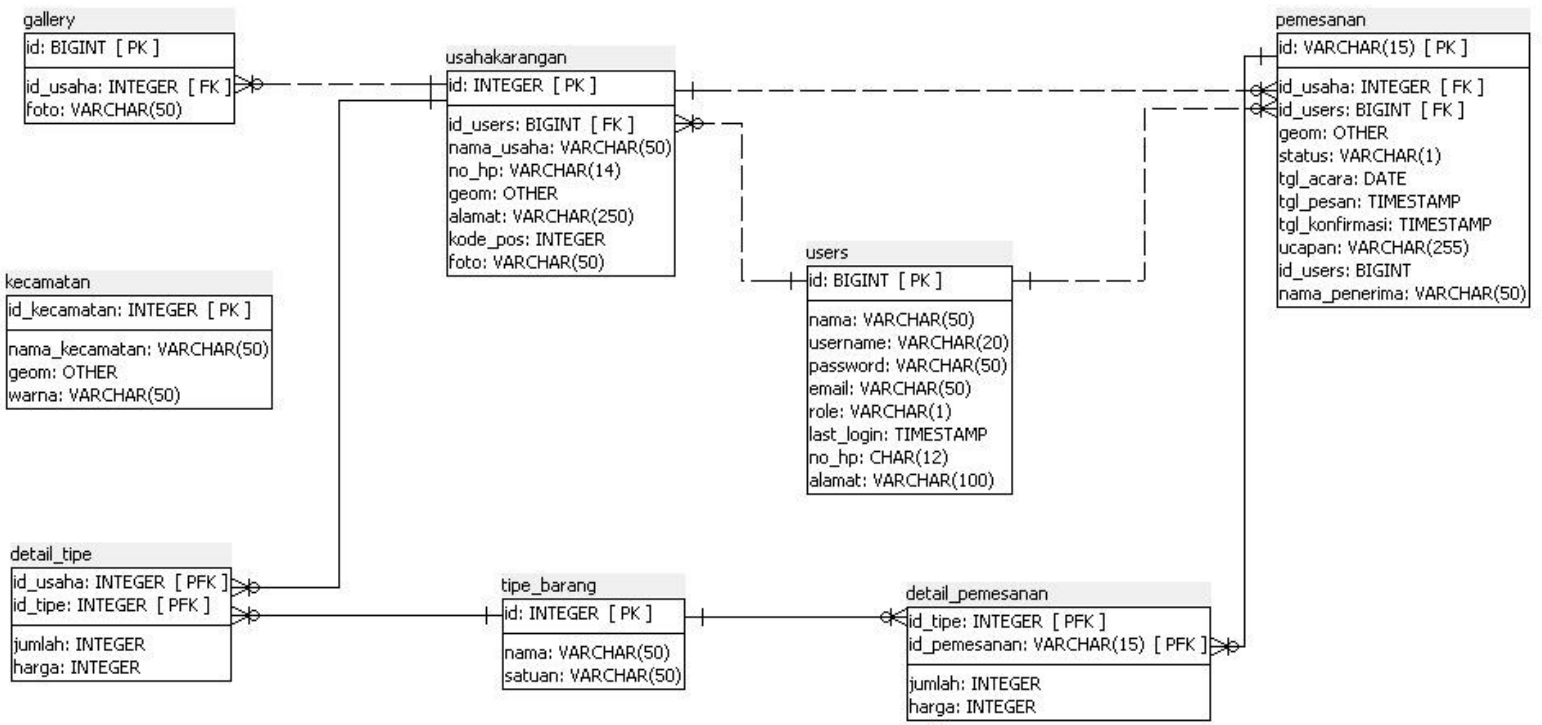

Gambar 6. Entity Relationship Diagram

\subsubsection{Rancangan User Interface}

User interface ini adalah tampilan antarmuka sistem yang berhubungan secara langsung dengan pengguna. Perancangan user interface pada SIG penyebaran lokasi usaha florist serta fitur pendaftaran pemesanan berbasis web di Kota Padang bertujuan untuk membantu pengguna dalam menggunakan aplikasi. Perancangan user interface dibuat sesuai dengan fungsional yang terdiri dari empat halaman yaitu, halaman awal (home), halaman calon pemesan, halaman admin pengelola usaha florist, dan halaman super admin yang dirancang dengan menggunakan aplikasi Balsamic Mockup.

Berikut beberapa contoh user interface yang dirancang untuk aplikasi SIG penyebaran lokasi usaha florist serta fitur pendaftaran pemesanan berbasis web di Kota Padang yaitu halaman utama aplikasi. Halaman utama (home) adalah halaman yang pertama kali ditampilkan ketika pengguna mengakses aplikasi. Pada halaman utama terdapat dua bagian SIG penyebaran lokasi usaha florist serta fitur pendaftaran pemesanan berbasis web di Kota Padang yaitu bagian kiri dan bagian tengah. Pada bagian kiri terdapat menu-menu pencarian sesuai dengan fungsional yaitu pencarian berdasarkan nama usaha, berdasarkan kecamatan dan berdasarkan barang tersedia. Pada bagian tengah terdapat icon sesuai dengan fungsional yaitu icon untuk menampilkan posisi saat ini, menampilkan posisi manual, menampilkan semua lokasi toko usaha florist, menampilkan legenda, dan radius. Pada bagian tengah ini juga terdapat nama aplikasi yang dibangun, peta Kota Padang, list hasil pencarian, dan informasi detail usaha florist. dapat dilihat pada gambar7. 


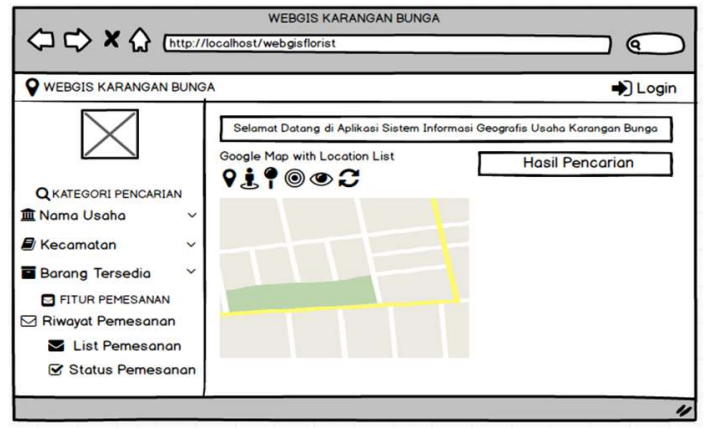

Gambar 7. Tampilan Rancangan Halaman Home

\subsubsection{Rancangan Proses}

Perancangan proses yang dibuat pada aplikasi SIG penyebaran lokasi usaha florist serta fitur pendaftaran pemesanan berbasis web di Kota Padang ini disajikan dalam bentuk use case scenario dalam menggambarkan aktivitas dan interaksi yang dilakukan oleh pengguna, super admin, admin pengelola usaha florist, dan berdasarkan fungsional sistem yang terdapat dalam use case diagram. Salah satu rancangan proses yaitu scenario melihat semua usaha florist. Perancangan proses ini diuraikan pada Tabel 1.

Tabel 1. Skenario Melihat Semua Usaha Florist

\begin{tabular}{ll}
\hline $\begin{array}{l}\text { Use Case } \\
\text { Name }\end{array}$ & Melihat semua usaha florist \\
\hline $\begin{array}{l}\text { Participal } \\
\text { Actor }\end{array}$ & Calom pemesan \\
\hline Flow of Event & 1. Calon pemesan memilih menu \\
& pencarian "Lihat Semua Florist" \\
& 2. Sistem menampilkan \\
& \multicolumn{1}{c}{ semua usaha florist } \\
\hline $\begin{array}{l}\text { Entry } \\
\text { Condition }\end{array}$ & $\begin{array}{l}\text { Calon pemesan telah membuka } \\
\text { aplikasi SIG penyebaran lokasi usaha } \\
\text { florist serta fitur pendaftaran } \\
\text { pemesanan berbasis web di Kota }\end{array}$ \\
\hline Padang \\
Condition & Calon pemesan melihat semua nama \\
usaha florist
\end{tabular}

\section{PEMBAHASAN}

Implementasi dari user interface ini mengacu pada bentuk rancangan yang telah dibahas pada bab sebelumnya. Tampilan user interface pada aplikasi ini menggunakan framework front-end bootstrap yang merupakan framework CSS yang menyediakan kumpulan komponen-komponen antarmuka dasar pada web yang telah dirancang untuk memudahkan pengguna dalam membangun dan mengembangkan website yang responsif dan menarik. Implementasi program aplikasi SIG penyebaran lokasi usaha florist serta fitur pendaftaran pemesanan berbasis web di Kota Padang menggunakan javascript dan bahasa pemrograman PHP untuk mengakses server.

\subsection{Implementasi User Interface Aplikasi}

Implementasi user interface berikut merupakan halaman home memuat peta wilayah Kota Padang yang sudah di digitasi per kecamatan dan juga icon button untuk melakukan beberapa aksi selanjunya dan juga terdapat result yang mana nantinya akan menampilkan data yang akan dicari, dapat dilihat pada Gambar 8 .

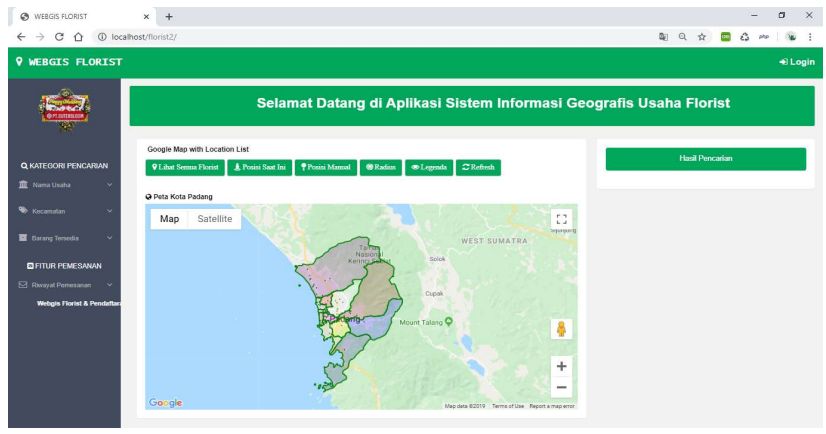

Gambar 8. Implementasi User Interface Halaman Home Pengujian Sistem

Tabel 2. Pengujian Pencarian Berdasarkan Nama

\begin{tabular}{|c|c|}
\hline \multicolumn{2}{|c|}{ Kasus dan Hasil Uji Berhasil } \\
\hline Aksi & $\begin{array}{l}\text { Calon Pemesan (Ajo) telah login sebelumnya } \\
\text { dan memilih usaha florist (Phapa Wedding } \\
\text { Solutions) lalu klik tombol "Order" disebelah } \\
\text { kanan di hasil pencarian, setelah itu isi semua } \\
\text { form berupa lokasi pengiriman, tanggal } \\
\text { pengiriman, ucapan, dan pilihan barang pesanan } \\
\text { dengan cara menekan checkbox barang sesuai } \\
\text { keinginan pemesan, setelah itu tekan tombol } \\
\text { "Pesan". }\end{array}$ \\
\hline Ekspetasi & $\begin{array}{l}\text { Data tersimpan dan muncul pemberitahuan anda } \\
\text { berhasil memesan barang serta menuju halaman } \\
\text { detail pendaftaran pemesanan yang telah } \\
\text { dilakukan }\end{array}$ \\
\hline Hasil & $\begin{array}{l}\text { Data tersimpan dan muncul pemberitahuan anda } \\
\text { berhasil memesan barang serta menuju halaman } \\
\text { detail pendaftaran pemesanan yang telah } \\
\text { dilakukan }\end{array}$ \\
\hline Kesalahan & Tidak ada \\
\hline Pengujian & Sesuai dengan ekspektasi \\
\hline \multicolumn{2}{|c|}{ Kasus dan Hasil Uji Alternatif } \\
\hline Aksi & $\begin{array}{l}\text { Calon Pemesan (Ajo) telah login sebelumnya } \\
\text { dan memilih usaha florist (Phapa Wedding } \\
\text { Solutions) lalu klik tombol "Order" disebelah } \\
\text { kanan di hasil pencarian, setelah itu isi semua } \\
\text { form berupa lokasi pengiriman, tanggal } \\
\text { pengiriman, ucapan, dan mengkosongkan } \\
\text { pilihan barang pesanan setelah itu tekan tombol } \\
\text { "Pesan". }\end{array}$ \\
\hline Ekspetasi & $\begin{array}{l}\text { Muncul notifikasi "Anda harus mencentang } \\
\text { setidaknya satu kotak centang". }\end{array}$ \\
\hline Hasil & $\begin{array}{l}\text { Muncul notifikasi "Anda harus mencentang } \\
\text { setidaknya satu kotak centang". }\end{array}$ \\
\hline Kesalahan & Tidak ada \\
\hline Pengujian & Sesuai dengan ekspektasi \\
\hline
\end{tabular}




\subsection{Pengujian Sistem}

Pengujian aplikasi pendaftaran pemesanan pada usaha florist di Kota Padang berbasis web dilakukan menggunakan metode blackbox testing dengan mengamati masukan yang diberikan kepada sistem dan luaran yang dihasilkan oleh sistem. Hasil dari pengujian dikatakan benar, jika luaran yang dihasilkan oleh sistem sama dengan yang dirancang dan jika tidak sama dengan kebutuhan fungsional sistem maka dinyatakan tidak berhasil dan perlu dilakukan perbaikan.

Salah satu pengujian yang dilakukan yaitu pengujian pengisian form pendaftaran pemesanan. Pengujian pengisian form pendaftaran pemesanan dapat dilihat pada Tabel 2. Hasil pengujian pencarian usaha florist berdasarkan nama pada web yang telah diisi dengan hasil uji berhasil dapat dilihat pada Gambar 9 dan Gambar 10.

Setelah melakukan pengujian pada sistem juga dilakukan pengujian SQL pada database. Hasil pengujian pada SQL database yaitu berupa $\mathrm{id}=50$, nama, alamat, longitude dan latitude yang dapat dilihat pada Gambar 13.

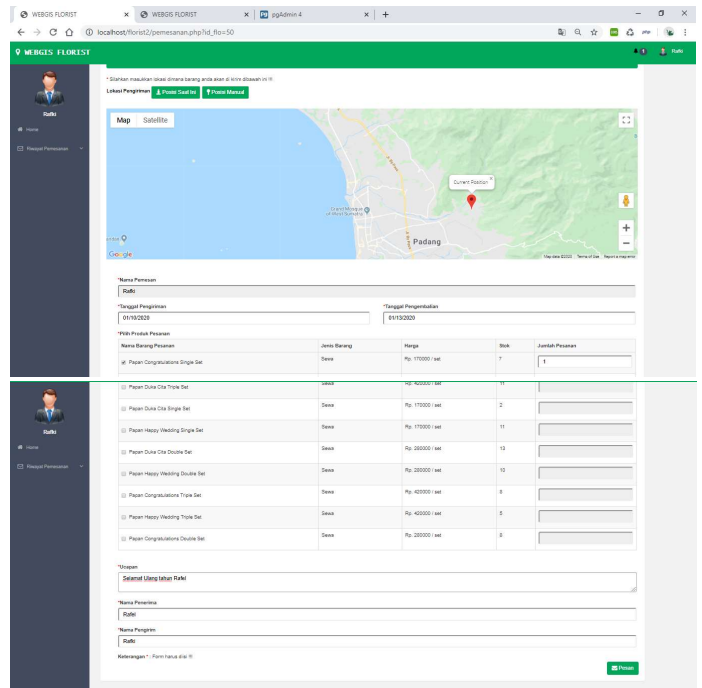

Gambar 9. Pengujian Pengisian Form Pendaftaran Uji Berhasil

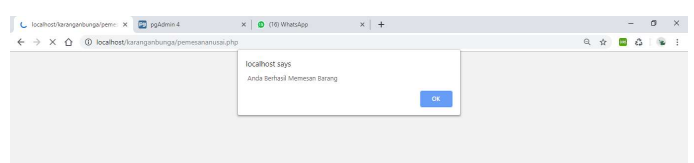

Gambar 10. Hasil Pengujian Pengisian Form Pendaftaran Berhasil

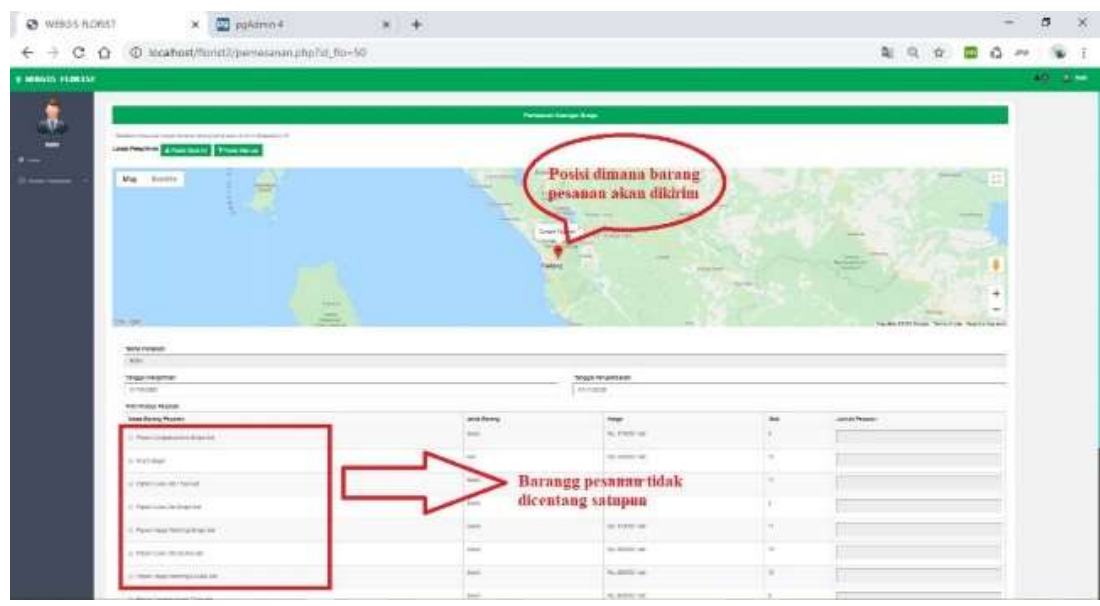

Gambar 11. Pengujian Pengisian Form Pendaftaran Uji Alternatif

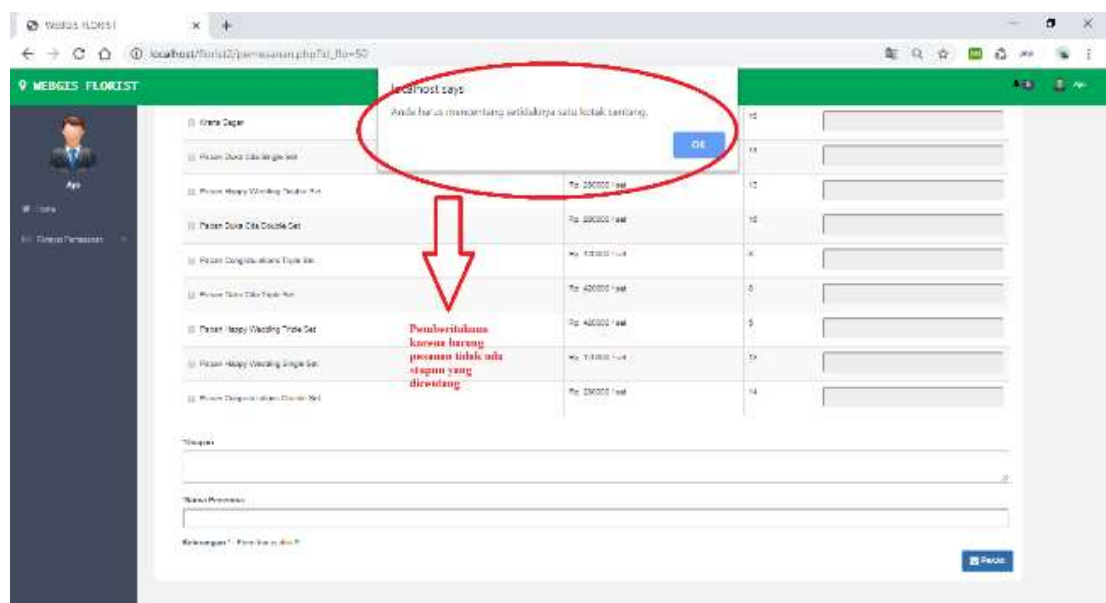

Gambar 12. Hasil Pengujian Pengisian Form Pendaftaran Uji Alternatif 


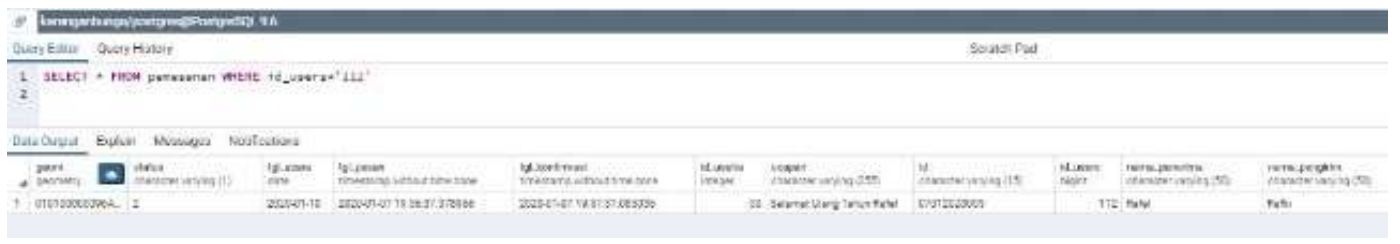

Gambar 13. Hasil Pengujian Query SQL Menampilkan Hasil Pendaftaran Pemesanan

Berdasarkan penelitian sebelumnya, fungsional yang terdapat pada penelitian sebelumnya berupa fungsional pencarian objek yang hasilnya akan ditamplikan pada peta dan fungsional pengelolaan data objek. Pada penelitain yang dilakukan, terdapat fungsional proses pendaftaran pemesanan. Proses pendaftaran pemesanan mengunakan google maps sebagai penanda lokasi pengiriman barang atau pesanan untuk membantu usaha florist mengurangi kesalahan saat mencari alamat lokasi pengriman barang atau pesanan juga telah berhasil dilakukan sesuai dengan hasil uji yang telah dijelaskan sebelumnya.

\section{KESIMPULAN}

Aplikasi SIG penyebaran lokasi usaha florist serta fitur pendaftaran pemesanan berbasis web di Kota Padang telah selesai dibangun dengan menerapkan metode waterfall yng meliputi tahap analisis, desain, pengodean, dan pengujian. Analisis kebutuhan fungsional dirumuskan dari analisis proses data, wawancara dan penelitian yang pernah ada. Hasil dari analisis menghasilkan 31 fungsional. Pada aplikasi SIG penyebaran lokasi usaha florist serta fitur pendaftaran pemesanan berbasis web di Kota Padang telah selesai dibangun dan dapat diakses pada alamat website https://webgisflorist.herokuapp.com. Berdasarkan hasil pengujian blackbox testing dari 31 fungsional yang terdapat pada aplikasi SIG penyebaran lokasi usaha florist serta fitur pendaftaran pemesanan berbasis web di Kota Padang diperoleh hasil bahwa sistem yang telah dibangun berjalan sesuai dengan rancangan yang dibuat.

\section{DAFTAR PUSTAKA}

[1] B. Setyono, "Prospek Pengembangan Agribisnis Bunga Potong Krisan Di Kecamatan Samigaluh Kulonprogo Di Kecamatan Samigaluh Kulonprogo," Agros, p. 2, 2016.

[2] V. H. Novianthi, "Analisis Strategi Pemasaran pada WId Florist Bogor," scientific Repository IPB, 2011.

[3] T. Lisetia, "Perancangan Program Penjualan Bunga Berbasis Web," Jurnal ABDIMAS BSI, 2016.

[4] D. K. d. U. K. P. DISKOPUKM, Interviewee, Daftar Usaha Florist di Kota Padang. [Interview]. Agustus 2019.

[5] E. Irwansyah, Sistem Informasi Geografis : Prinsip Dasar Dan Pengembangan Aplikasi, Yogyakarta: Digibooks, 2013.
[6] Masykur, "Implementasi Sistem Informasi Geografis Menggunakan Google Maps API dalam Pemetaan Asal Mahasiswa," SIMETRIS, p. 2, 2014.

[7] I. G. W. Y. Lesmana, I. K. A. Purnawan and I. M. Sukarsa, "Aplikasi Sistem Informasi Geografis Tempat Usaha di Wilayah Denpasar Berbasis Mobile Android," MERPATI VOL. 2, p. 3, 2014.

[8] Z. R. Maharoesman, D. Suwardhi and A. Indrajaya, "Pembangunan Sistem Informasi Geografis Berbasis Web untuk Kegiatan Ekskavasi Situs Warisan Budaya Indonesia (Studi Kasus: Komplek Candi Batujaya)," Jurnal Konservasi Cagar Budaya Borobudur, 7(2), vol. 7(2), pp. 35-43, 2013.

[9] Y. Hartadi, "Perancangan Sistem Informasi Lokasi Lembaga Bimbingan Belajar di Kota Padang," Jurnal TEKNOSI, 2015.

[10] H. Setiady and Yulistia, "Sistem Informasi Pemesanan Dan Penjualan Berbasis Web Pada Dewi Florist," 2013.

[11] A. Agustian, S. Rahayu and L. Nurlani, "Aplikasi E-Futsal dengan Metode Mobile-GIS dan GPS Berbasis Android," Jurnal Teknologi Rekayasa, vol. III, pp. 115-128, Juni 2018.

[12] W. Y. P. Taroreh, "Sistem Informasi Penjualan Bunga Berbasis Web," vol. 4, p. 3, 2014.

[13] Y. Nuryamin and S. Dewi S, "Rancang Bangun Sistem Informasi Penjualan Buket Bunga Kain Flanel Florist Menggunakan Metode Waterfall," Jurnal Riset Komputer (JURIKOM), vol. V, pp. 449-453, Oktober 2018.

[14] T. Antonio, N. Widyastuti and C. Iswahyudi, "Perancangan dan Pengembangan Sistem Infomasi pada Toko Bunga Amai," Jurnal SCRIPT, vol. II, Desember 2014.

[15] S. Nidhra and J. Dondeti, "Black box and white box testing techniques-a literature review," International Journal of Embedded Systems and Applications (IJESA), vol. 2, no. 2, pp. 29-50, 2012.

[16] R. Anggrainingsih, S. P. Yohanes and U. Salamah, "Analisis Dan Verifikasi Workflow Menggunakan Petri (Studi kasus; Proses Bisnis di Universitas Sebelas Maret)," 2014. 